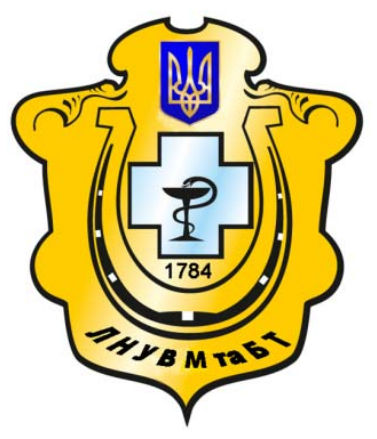

Науковий вісник Львівського національного університету ветеринарної медицини та біотехнологій імені С.3. Гжицького

Scientific Messenger of Lviv National University of Veterinary Medicine and Biotechnologies named after S.Z. Gzhytskyj

doi:10.15421/nvlvet6604

ISSN 2413-5550 print

ISSN 2518-1327 online

$\underline{\text { http://nvlvet.com.ua/ }}$

УДК 619:616.-091:619:578.822.:636.7

\title{
Морфологічні особливості міокардіальної форми парвовірусної інфекції собак
}

\author{
Б.В. Борисевич, В.В. Лісова, А. Шацька \\ lisovav@ukr.net
}

Національний університет біоресурсів і природокористування Украӥни, вул. Героїв Оборони, 11, м. Київ, 03041, Украӥна

\begin{abstract}
Представлені результати вивчення морфологічних особливостей патологічного прочесу за міокардіальної форми парвовірусної інфекиії собак. Визначені основні критерії ї̈ посмертної діагностики.

Показано, що міокардит парвовірусної етіології на підставі результатів патоморфологічного дослідження чітко диференціюється від інших смертельних хвороб, щяо уражають иуценят.

У иуценят віком від 1-го до 4-х тижнів, які гинули раптово, без клінічних ознак і біохімічних змін крові, характерних для міокардиту, були виявлені патоморфологічні ознаки міокардіальної форми парвовірусної інфекції собак.

При гістологічному дослідженні виявляли характерні морфологічні зміни: 1) лімфоїдочитарний (негнійний) міокардит; 2) еозинофільні тільия-включення в ядрах кардіоміоцитів; 3) набряк строми серия; 4) зернисту дистрофію кардіоміоцитів; 5)некроз кардіоміоцитів з деструкиією м'язових волокон міокарду.

Також неспецифічними але постійними морфологічними ознаками, щчо виникали внаслідок порушення кровообігу й серцевої недостатності були венозна гіперемія печінки, нирок і набряк легень.

Ключові слова: иуценята, парвовірусна інфекція, міокардіальна форма, макроскопічні зміни, гістологічні зміни, міокардит, лімфочити, тільия-включення, набряк, некроз.
\end{abstract}

\section{Морфологические особенности миокардиальной формы парвовирусной инфекции собак}

\author{
Б.В. Борисевич, В.В. Лисовая, А. Шацкая \\ lisovav@ukr.net \\ Национальный университет биоресурсов и природопользования Украинь,, \\ ул. Героев Обороны, 11, Киев, 03041, Украина
}

\begin{abstract}
Представлены результаты изучения морфологических особенностей патологического прочесса при миокардиальной форме парвовирусной инфекиии собак. Определены основные критерии их посмертной диагностики.

Показано, что миокардит парвовирусной этиологии на основании результатов патоморфологического исследования четко дифференцируется от других смертельных заболеваний, поражающих щенков.

У щенкков в возрасте от 1-й до 4-х недель, которые погибали внезапно, без клинических признаков и биохимических изменений крови, характерных для миокардита, были выявлены патоморфологические признаки миокардиальной формы парвовирусной инфекиии собак. При гистологическом исследовании выявляли характерные морфологические изменения: 1) лимфоидоцитарный (негнойный) миокардит; 2) эозинофильные тельца-включения в ядрах кардиомиоцитов; 3) отек стромы сердиа; 4) зернистую дистрофию кардиомиочитов; 5) некроз кардиомиоичтов с деструкиией мыпеечных волокон миокарда.

Также неспецифическими но постоянными морфологическими признаками, возникавшими вследствие нарушения кровообращения и сердечной недостаточности были венозная гиперемия печени, почек и отек легких.
\end{abstract}

\section{Citation:}

Borysevych, B., Lisova, V., Shats'ka, A. (2016). Morphological features of myocardial form of canine parvoviral infection. Scientific Messenger LNUVMBT named after S.Z. Gzhytskyj, 18, 2(66), 16-19. 
Ключевые слова: щенки, парвовирусная инфекиия, миокардиальная форма, макроскопические изменения, гистологические изменения, миокардит, лимфоциты, тельияа-включения, отек, некроз.

\title{
Morphological features of myocardial form of canine parvoviral infection
}

\author{
B. Borysevych, V. Lisova, A. Shats'ka \\ lisovav@ukr.net \\ National University of life and environmental sciences of Ukraine, \\ Heroyiv Oborony Str., 11, Kyiv, 03041, Ukraine
}

Presented results of studying of morphological features of the pathological process at the cardial form of parvovirus infection of dogs. Identified the main criteria for it post-mortem diagnostics.

It is shown that based on the results of pathological studies myocarditis of the parvovirus etiology clearly differentiate from other deadly diseases that affect puppies.

In puppies aged 1 to 4 weeks, who died suddenly without clinical signs and biochemical changes of blood, which are characteristic for myocarditis, was detected pathomorphological signs of myocardial forms of parvovirus infection of dogs.

Histological examination revealed the characteristic morphological changes: 1) lymphocytic (purulent) myocarditis 2) eosinophilic inclusion-bodies in nuclei of cardiomyocytes 3) stromal edema 4) granular dystrophy of cardiomyocytes 5) necrosis of cardiomyocytes with the destruction of the muscle fibers of the myocardium.

Also nonspecific but constant morphological features, that is caused by circulatory disorders and heart failure was venous hyperemia of the liver, kidney and pulmonary edema.

Key words: puppies, parvoviral infection, myocardial form, gross changes, microscopic changes, myocarditis, lymphocytes, inclusion-bodies, edema, necrosis.

\section{Вступ}

Проблема парвовірусної інфекції займає провідне місце в інфекційній патології собак і котів. Вона $\epsilon$ широко розповсюдженою вірусною хворобою серед домашніх та безпритульних собак та котів. Парвовірусна інфекція часто реєструється лікарями ветеринарної медицини на території України та $є$ досить поширеною у всьому світі (Nedosjekov and Sereda, 2015).

Найвагоміша частка сучасних наукових робіт присвячена оцінці реальної поширеності варіантів CPV-2 в популяції домашніх собак, вивченню чутливості діагностичних тестів й ефективності вакцинації (Hong et al., 2007; Vieira et al., 2008; Schmitz et al., 2009).

Морфологія хвороби в країнах далекого зарубіжжя вивчалася окремими авторами в кінці 70-х - у 80-х роках минулого століття (Thompson et al., 1979; Carpenter et al., 1980; Kelly and Atwell, 1998), в останнє десятиріччя є невелика кількість повідомлень щодо патоморфологічних досліджень даної хвороби. На нашу думку, найменш висвітленими аспектами парвовірусної інфекції собак лишаються іiі патогенез і морфологічні особливості за різних форм хвороби.

Метою дослідження було вивчити морфологічні особливості розвитку патологічного процесу за міокардіальної форми парвовірусної інфекції собак і визначити критерії патоморфологічної діагностики хвороби.

Для досягнення мети вирішувались наступні задачі:

- визначити макроскопічні характеристики міокардіальної форми парвовірусної інфекції;

- визначити патогістологічні зміни за міокардіальної форми парвовірусної інфекції.

\section{Матеріал і методи досліджень}

Матеріалом дослідження слугували трупи цуценят різних порід віком від 1-го до 4-х тижнів $(\mathrm{n}=8)$, які гинули раптово, без клінічних ознак. Діагноз на парвовірусну інфекцію був підтверджений у ПЛР. Пато- морфологічне дослідження включало: проведення патологоанатомічного розтину, під час якого фіксували й вивчали макроскопічні зміни в органах і тканинах і гістологічне дослідження відібраного патологічного матеріалу.

Патологічний матеріал фіксували в 10\% - вому водному розчині нейтрального формаліну й заливали в парафін. Виготовлені гістозрізи фарбували гематоксиліном Караці й еозином за стандартними прописами (Goralskij et al., 2011). Мікроструктурні зміни в гістопрепаратах досліджували під світловим мікроскопом MC 100LED (Micros Austria) при збільшеннях від 70 до 1000.

\section{Результати та їх обговорення}

При зовнішньому огляді трупів цуценят в більшості випадків відзначалася синюшність видимих слизових оболонок, інші макроскопічні зміни при зовнішньому огляді не реєструвалися.

При проведенні патологоанатомічного розтину трупів загиблих тварин в більшості випадків $(\mathrm{n}=6)$ виявляли збільшення серця з виразним розширенням, як лівих, так і правих передсердь й шлуночків. Унаслідок розширення камер серця відбувалося збільшення його розмірів і зміна форми до більш округлої. Його кровоносні судини були розширені, переповнені кров'ю. У 2-х випадках реєструвалося розширення лише правої половини органу зі зміщенням верхівки серця вліво. У таких випадках виявляли тільки морфологічні ознаки венозного застою і набряку легень.

У міокарді часто виявляли майже білі ішемічні ділянки у вигляді смужок або плямок. При цьому такі вогнища в різних цуценят мали різні розміри, форму i локалізацію. Консистенція змінених ділянок була пружною. У одному випадку міокард був дифузно блідо-сірого, майже білого кольору.

У легенях, як і в просвіті трахеї і бронхів на розрізі виділяється рожева піниста рідина. Вони мали тісту- 
вату консистенцію, рівномірне рожеве забарвлення. Шматочки органу важко плавали у воді.

У печінці й нирках цуценят спостерігали морфологічні ознаки пасивної венозної гіперемії. При цьому печінка мала дифузно темно-червоний колір, 3 поверхні розрізу виділялася темно-червона кров. Проте значне збільшення органу в жодному з випадків не реєструвалось.

Нирки набували синюшного відтінку. На розрізі границя між кірковою і мозковою речовинами була згладжена, поверхня розрізу мала підвищену вологість. Слід відмітити, що венозний застій печінки і нирок виявлявся саме в тих собак $(\mathrm{n}=6)$, в яких було знайдено розширення лівого шлуночка серця.

При проведенні гістологічних досліджень серця тварин, нами було встановлено, що його мікроскопічна будова зазнає значних змін.

Найбільш виразні зміни локалізувалися в м'язовій тканині органу і в міжм'язовій сполучнотканинній стромі. Артерії, артеріоли, вени і венули були розширені, переповнені кров'ю. Строма органу була нерівномірно набрякла. При цьому багато пучків колагенових волокон були нерівномірно потовщені й мали гомогенний вигляд, оскільки окремі волокна в складі пучків не диференціювалися. Частина колагенових волокон і їх пучків при зафарбовуванні гематоксиліном i еозином були помірно чи виразно базофільними, що свідчить про зміни їх фізико-хімічних властивостей. Частина колагенових волокон піддавалася лізису.

Крім набряку реєструвалась вогнищева інфільтрація строми клітинами крові. Серед клітин крові переважали лімфоцити і моноцити. Проте місцями реєструвались невеликі осередки скупчень еозинофілів.

Більшість кардіоміоцитів перебувала в стані зернистої дистрофії, зумовленої порушенням кровообігу і набряком в результаті запальної реакції. У ядрах деяких 3 них виявлялись еозинофільні тільцявключення, що мали різні форму, розміри і локалізацію. Частина ядер кардіоміоцитів, які містили еозинофільні тільця-включення, втрачали свою правильну округлу чи овальну форму. Форма тілець-включень в більшості випадків була округлою чи овальною, але в деяких ядрах вони мали неправильну форму. У більшості випадків такі включення локалізувались на периферії ядра, але в окремих кардіоміоцитах займали центральну частину ядра, відтісняючи нуклеоплазму в периферичні його відділи. Розміри тілець-включень також були різними. У одних клітинах вони займали $16,4 \pm 2,7 \%$ загальної площі ядра. Хроматин при цьому був нерівномірно більш інтенсивно зафарбований, ніж в ядрах кардіоміоцитів, які не містили тілецьвключень. У інших кардіоміоцитах тільця-включення мали більші розміри, сягаючи $88,7 \pm 6,4 \%$ загальної площі ядра. Хроматин при цьому був зафарбований набагато більш інтенсивно, ніж в ядрах клітин, які не містили тілець-включень.

Частина кардіоміоцитів перебували на різних стадіях некрозу. Унаслідок руйнування частини м'язових клітин місцями знаходили розволокнення і фрагментацію м'язових волокон. Окремі пучки м'язових волокон руйнувались майже повністю. У епікарді й ендокарді мікроскопічні зміни в жодному з випадків нами знайдені не були. У легенях реєструвалось потоншання стінок альвеол, яке можливо спричинене серцевою недостатністю.

Одже, міокардит парвовірусної етіології на підставі результатів патологоанатомічного розтину чітко диференціюється від інших смертельних хвороб, що уражають цуценят. Тому, на нашу думку, міокардіальну форму парвовірусної інфекції собак можна називати «парвовірусний міокардит».

\section{Висновки}

У цуценят віком від 1-го до 4-х тижнів, які гинули раптово, без клінічних ознак виявляли патоморфологічні ознаки міокардіальної форми парвовірусної інфекції. При гістологічному дослідженні виявляли характерні морфологічні зміни: 1) лімфоїдоцитарний (негнійний) міокардит; 2) еозинофільні тільцявключення в ядрах кардіоміоцитів; 3) набряк сполучнотканинної строми серця; 4) зернисту дистрофію кардіоміоцитів; 5) некроз кардіоміоцитів 3 деструкцією м'язових волокон міокарду.

Також неспецифічними але постійними морфологічними ознаками, що виникали внаслідок порушення кровообігу й серцевої недостатності були венозна гіперемія печінки й нирок і набряк легень.

Перспективи подальших досліджень. 3 метою вивчення патоморфологічної картини міокардіальної форми хвороби, наступним етапом доцільно провести вивчення морфологічних особливостей за даної патології з використанням гістохімічних методів дослідження.

\section{Бібліографічні посилання}

Nedosjekov, V.V., Sereda, O.M. (2015). Analiz evolucii rozvytku ta poshyrennya parvovirusnoij infekcij sobak ta kotiv (literaturnyij oglyad) [Analysis of evolution of developing and spreading of parvoviral infection of dogs and cats (Literature review)]. Scientific and Technical Bulletin of Research Center of biosafety and environmental control of resource agro-industrial complex, 3(3), 75-78 (in Ukrainian).

Vieira, MJ, Silva, E, Oliveira, J, et al. (2008). Canine parvovirus 2c infection in central Portugal. J Vet Diagn Invest. 20(4), 488-91

Hong, C, Decaro, N, Desario, C, et al. (2007). Occurrence of canine parvovirus type $2 \mathrm{c}$ in the United States. J Vet Diagn Invest. 19(5), 535-539.

Schmitz, S., Coenen, C., Konig, M., Thiel, H. and Neiger, R. (2009). Comparison of three rapid commercial Canine parvovirus antigen detection tests with electron microscopy and polymerase chain reaction. J. Vet. Diagn. Invest. 21, 344-345.

Carpenter, J.L., Roberts, R.M., Harpster, N.C., et al. (1980). Intestinal and cardiopulmonary forms of parvovirus infection in litters of pups. JAVMA. 176, 11, 1269-1273.

Thompson, H., McCandlish, I.A.P., Cornwell, H.J.C., et al. (1979). Myocarditis in puppies. Veter. Rec. 104, 107-108. 
Kelly, W.R., Atwell, M.M. (1998). CPVI in Australia and in the world. Austral. Veter. J. 86(1), 36-49.

Goralskij, L.P., Homych, V.T., Kononskij, O.I. (2011). Osnovy histologichnoyi tehniky i morfofunkcionalni metody doslidjen u normi ta pry patologiyi [Founda- tions of histological engineering and morphofunctional methods of research in norm and pathology]. Jytomir, Ukrainian: Polissya (in Ukrainian).

Стаття надійшла до редакиії 28.09.2016 